\title{
Sastra dan sufisme (Studi terhadap Dîwân al-Durr al-Manzhûm li Dzawi al- 'Uqûl wa al-Fuhûm karya Syaikh Abdullah al-Haddâd)
}

\author{
Idrus al-Kaf \\ Fakultas Ushuludin dan Pemikiran Islam UIN Raden Fatah \\ Email : skriptoria_ppsrf@yahoo.com
}

\begin{abstract}
Introduction. This article means to reveal some important aspects of the poetry of Syaikh al-Haddâd, and the characteristics of the Dîwân.

Data Collection Method. Using a literary approach methode

Analysis Data. The data were descriptively analysed by philosophical, and hermeneutical approaches

Results and Discussions. The poetry of Syaikh al-Haddâd are the theoretical Sufi poems that are rich in spiritual ideas and experiences. His poetries can be classified into the types of "syi'r al-kasyf wa al-ilham", it written through the kasyf experience or spiritual vision, because the author has achieved mystical and mystical unity. The author's study to the outer and the inner structure of Dîwân, has strengthened the conclusions that the poetries in dîwân are not a product of reason (logic), but are based more on the "mauhibah Rabbâniyah", a kind of inpersonal power, and looks very spontaneous and natural.

Conclusions. poetry is a medium that is often used by the Sufis to express their Sufism thoughts. because it is through this symbolic and imagery language that the Sufis can give readers the opportunity to improve the "reflection of the beauty of the world" ascending in to "the reflection of divine beauty".".
\end{abstract}

Keyword : literature, sufism, poetry of Syaikh al-Haddâd

\section{A. PENDAHULUAN}

Pemikiran tasawuf mengalami perkembangan yang cukup unik dan menarik. Dikatakan demikian karena di satu sisi pemikiran-pemikiran sufistik telah menimbulkan tensi-tensi ideologis yang sangat tajam; digantungnya Abû Mansûr al-Hallâj dikarenakan konsep Anâ al-Haq-nya, adalah suatu bukti nyata untuk hal ini. Di sisi lain pemikiran sufistik mampu melahirkan dinamika intelektual Islam secara lebih positif. Ini terlihat dari peran para tokohnya yang memiliki pengaruh yang cukup besar, baik di belahan timur maupun di belahan barat dunia, seperti Jalaluddîn Al-Rûmi, Ibn `Arabi dan lain sebagainya.

Keunikan lainnya dari tasawuf adalah terletak pada objek kajiannya yang bersifat esoteris, ia berkaitan dengan dimensi batiniah seseorang. Hal ini berbeda 
dengan permasalahan fiqh, yang objek pengkajiannya lebih menekankan aspekaspek lahiriah (formal) saja. Maka terma-terma di dalam tasawuf dirasakan lebih universal dan inklusif, lebih lentur, luas dan terbuka.

Tasawuf bersifat esoteris, karena berkenaan dengan perasaan batin yang paling dalam, dan merupakan pengalaman pribadi seorang sufi ketika sedang berhubungan dengan Tuhannya, ia berkaitan dengan rahasia-rahasia serta simbolsimbol yang rumit dan tidak dapat dipahami secara gamblang oleh orang awam. Oleh karena itu, tasawuf membutuhkan suatu media yang tepat untuk mengungkapkan dirinya secara benar, agar tidak menimbulkan konflik dan ketegangan-ketegangan di masyarakat awam. Adapun media tersebut adalah seni (dalam hal ini tentu saja seni Islam). Baik itu berbentuk tarian, nyanyian maupun berbentuk syair.

Seni sastra, khususnya yang berbentuk syair atau prosa, mempunyai hubungan yang sangat erat dengan spiritualitas Islam. Karena ajaran Islam itu didasarkan pada tuntunan Tuhan yang diwahyukan sebagai kitab suci -yang notabene bercorak prosa-, maka sastra dapat menempati posisi yang utama diantara berbagai bentuk seni lainnya yang ada di seluruh masyarakat Islam. ${ }^{1}$

Selain itu, baik seni maupun sufisme sama-sama menjadikan cinta sebagai salah satu tema sentral mereka. Para penyair sufi merupakan penghubung antara tradisi keagamaan dan tradisi sastra. Hal ini dimungkinkan bukan saja karena sebagian dari mereka itu adalah para ulama. Namun juga oleh karena pengalaman dan penghayatan estetik yang memainkan peranan penting dalam usaha mereka untuk mencapai Tuhan, pada puncaknya mempunyai kualitas religius dan mistis karena menyentuh dunia yang spiritual dan transenden. ${ }^{2}$

Dan pengalaman estetik bertalian dengan keindahan yang spiritual dan supranatural ini. Dalam bukunya yang terkenal Futuhât al-Makiyyah, Ibn `Arabi ${ }^{3}$

Seyyed Hossein Nasr, Islamic Art and Spirituality, (New York: State University of New York Press, 1963): 4-5

Muslim bin al-Hajjâj al-Naisâbûri, Shahih Muslim, (Beirut: Dâr Ihyâ al-Turâts al-Arabi, tt): $93^{2}$

Ibn 'Arabi membagi cinta menjadi tiga: cinta alami, cinta kerohanian dan cinta ilâhi, Cinta alami dan cinta kerohanian merupakan jenis-jenis dari cinta ilâhi. Dengan cinta ilâhi dia maksudkan adalah cinta hakiki daripada Yang Esa -cinta kekal yang merupakan sumber dari jenis-jenis cinta yang lain. Dikutip dari Abdul Hadi W.M. Sastra Sufi, sebuah Antologi, (Jakarta: Pustaka Firdaus, 
menyatakan bahwa keindahan merupakan dasar dari cinta. Dan cinta kepada Tuhan memainkan peranan sentral sekali dalam ajaran sufi, sebab, ia merupakan salah satu faktor penopang yang fundamental dari pada manifestasi Hakekat yang Esa, yaitu Tuhan.

Dalam perkembangan tasawuf, banyak terdapat sufi besar yang memilih syair sebagai media dalam mengkomunikasikan pemikiran mistis mereka, sehingga menjadikan tasawuf berkembang secara estetis dalam suatu gaya yang tinggi di luar jangkauan akal murni. Syair-syair mereka terasa sedemikian mistis, baik dalam kandungan isi maupun inspirasinya, hal ini tentu saja disebabkan oleh ketinggian intelektual, kedalaman imajinasi mereka serta penghayatan estetis mereka yang begitu indah. Kita mengenal Râbi’ah al-`Adawiyah dengan syair mahabbah-nya yang begitu terkenal. Ada juga Sanầi, seorang sufi yang menggumuli sastra sejak paruh pertama abad ke-6 $\mathrm{H}$, yang merupakan pujanga sufi Persi pertama yang sangat produktif dalam memaparkan doktrin-doktrin tasawufnya melalui media syair. Epiknya yang berbentuk matsnâwi berjudul "Hadîqat al-Haqiqat"-nya menjadi sebuah model bagi penulis-penulis kemudian. ${ }^{4}$

Fariduddin `Attâr, yang tumbuh dan berkembang sekitar 60 tahun setelah Sana $i$, adalah seorang pengarang yang jauh lebih produktif. Ia menulis sebuah risalah yang sedemikian agung dan bernilai tentang biografi-biografi para wali dan sufi (Tadzkirah al-Auliyâ'). Syair-syair matsnâwi-nya mencakup tiga utama, Asrâr Nâma (Kitab Rahasia-Rahasia), tentang asas-asas utama tasawuf.; Ilâhi-nâma (Kitab Ilâhi), tentang cinta mistik; dan Manthiq al-Thair (Percakapan BurungBurung), sebuah kiasan yang benar-benar indah dalam melukiskan perjalanan sang mistikus menuju kemanunggalan dengan Tuhan. ${ }^{5}$

Di kalangan Bâ `alawi, ${ }^{6}$ banyak juga tokoh sufi sekaligus penyair, yang

1996): vi-vii

A.J. Arberry, Pasang Surut Aliran Tasawuf, Diterjemahkan oleh Bambang Herawan, (Bandung: Mizan, 1993): 139-143

ibid, 144

${ }^{6}$ Bâ `alawi adalah nama bagi satu komunitas yang keturunannya bersambung pada Imam Alwi bin 'Ubaidillah bin Ahmad bin Isa al-Muhajir. Perkembangan nasab mereka setelah abad ke-6 terjadi pada tiga jalur, yaitu 1) dari jalur Muhammad bin Ali bin Alwi bin Muhammad bin Alwi bin Ubaidillah, yang dikenal dengan Shahib al-Mirbath (w. 556), 2) Imam Alwi yang biasa disebut 'Am al-Faqîh al-Muqaddam, dan 3) Imam Ali bin Muhammad, ayah al-Faqîh al-Muqaddam. Lihat 
menyumbangkan gagasan-gasasan sufistik mereka melalui bait-bait syair. Satu di antaranya adalah Sayyid Abdullâh bin Alwi al-Haddâd (1044-1132 H), seorang sufi yang lahir di pinggiran kota Tarim (Hadhramaut), ${ }^{7}$ yang juga dikenal sebagai salah seorang tokoh sufi yang cukup berpengaruh. Ia dianggap sebagai pencetus tarekat al-Haddâdiyah. ${ }^{8}$

Salah satu karya monumental al-Haddâd, yang sampai sekarang masih terasa pengaruhnya di kalangan muslim di dunia, adalah kumpulan syair-syair beliau Diwân al-Durr al-Manzhûm li Dzawi al-`Uqûl wa al-Fuhûm.

Syaikh al-Haddâd memilih media syair untuk menyampaikan buah pikirannya yang tertentu, karena sikap kehati-hatiannya, yang merupakan sikap pribadinya dalam berbagai sektor kehidupan. ${ }^{9}$ Banyak pemikiran sufistik Syaikh alHaddâd yang tak termuat dalam kitab-kitabnya yang lain, tetapi dimuat dalam dîwân syairnya tersebut. ${ }^{10}$

Syair-syair Syaikh al-Haddâd memiliki beberapa kekuatan, yang menurut hemat penulis perlu dikemukakan di dalam tulisan ini. Dari segi materi, syair-syair Syaikh al-Haddâd mempunyai cakupan lapangan pembahasan yang begitu luas, tidak hanya terbatas pada masalah-masalah cinta, `isyq, rindu. Tapi juga membahas tentang ilmu-ilmu keislaman, keimanan dan tasawuf, doa-doa dan munajat, pujian serta wejangan-wejangan beliau kepada mereka yang mengalami kekeringan spiritual. Untaian bait-bait syairnya bagaikan mutiara yang memancarkan sinar cahaya ilâhiyah, yang dapat memberikan ketenangan hati dan ketentraman jiwa yang gelisah, serta membangkitkan semangat bagi pembacanya untuk menghadapi kehidupan ini.

Muhammad Ahmad al-Syâtiri, Siyâr as-Salaf min Banî Alawi al-Husainiyyîn, (Jeddah: 'Alam alMa'rifah, 1985): 16

7 Snouck Hurgronje, Nasehat-nasehat Snouck Hurgronje Semasa Kepegawaiannya di Hindia Belanda, (Jakarta: INIS), Vol.8: 1474-5

${ }^{8}$ Nama tarekat ini dinisbahkan kepada tokoh perintisnya Syaikh Abdullah bin Alwi al-Haddâd. Tarekat ini merupakan bagian dari tarekat al-`Alawiyyah, yang keabsahan dan validitas ajaranajarannya sebagai sebuah tarekat dapat dilihat dari adanya kesinambungan dalam menerima ijâzah dari Syaikh al-Haddâd, hingga kepada Rasulullah saw melalui Imam Ali bin Abî Thalib.

${ }^{9}$ Muhammad bin Zein bin Smith, Ghâyah al-Qashd wa al-Murâd, (Beirut: Dâr Ihyâ al-Kutûb al'Arabi, tt): 282

${ }^{10}$ Lihat Muhammad bin Abû Bakar al-Syilli, al-Masyra` al-Râwi fi Manâqib al-Kirâm Sâdah Bâ'alawi, juz 2, (Beirut: Dâr al-Ilm li al-Malâyin, tt): 64 
Dari segi bahasa, nampak sekali keluasan dan kedalaman pengetahuan bahasanya. Kata-kata yang ia digunakan dalam syair-syairnya adalah kata-kata yang indah dan mudah dicerna, bahasa yang digunakan adalah bahasa yang lugas dan sederhana sehingga mudah untuk difahami.

Husn al-takhallus (perpindahan pembicaraan yang halus dari satu tema kepada tema pembicaraan lainnya), merupakan salah satu aspek yang menjadi kekuatan di dalam syair-syair Syaikh al-Haddâd. Membaca syair-syairnya, kita tidak akan merasakan perpindahan satu tema kepada tema lainnya, sehingga tanpa terasa kita sudah berada pada permasalahan yang lain. Satu hal yang menunjukkan akan keluasan imajinasi beliau. Ditambah lagi dengan metode dan ushlûb yang ia gunakan dalam bersyair semakin menunjukan bahwa ia bukan saja seorang sufi, tetapi seorang intelektual jenius yang telah mendapatkan wahbah ilâhiyah berupa ilmu laduni.

Tulisan ini berupaya mengungkapkan beberapa aspek penting dari syairsyair Syaikh al-Haddâd tersebut, dan menyajikan gambaran berkenaan dengan kepenyairannya. Kajian semacam ini, berdasarkan hasil penelusuran penulis, belum pernah dilakukan oleh para peneliti tasawuf, khususnya di Indonesia. Kajian ini tentunya diharapkan dapat menambah wawasan akademis bagi peminat bidang kajian ini, khususnya yang terkait dengan masalah hubungan antara tasawuf dan seni sastra.

\section{B. METODE PENELITIAN}

Kajian tentang hubungan antara seni sastra dan tasawuf di dalam Diwân al-Durr al-Manzhûm li Dzawi al-`Uqûl wa al-Fuhûm, karya Syaikh Abdullah bin Alwi alHaddâd ini merupakan studi literatur (library research), yang menggunakan metode deskriptif analitis. Sumber primer dari penelitian ini adalah Diwân terkait yang diterbitkan di Mesir, oleh Mathba`ah Isa al-Bâbi al-Halabi wa Syarîkuhu, tt. Sedangkan sumber sekundernya adalah karya-karya Syaikh al-Haddad lainnya, dan tentu saja karya karya tasawuf lain yang terkait dengan masalah yang diteliti.

Data-data yang telah dikumpulkan dianalisis dengan menggunakan beberapa pendekatan, yaitu pendekatan filosofis, pendekatan hermeneutik, dan 
pendekatan ilmu sastra.

\section{HASIL DAN PEMBAHASAN}

\section{Sang sufi dan Dîwân-nya}

Syaikh Abdullah bin Alwi al-Haddâd ${ }^{11}$ dilahirkan pada tanggal 5 Shafar 1044 H di kota Tarim pada sebuah distrik yang bernama Subair di propinsi Hadhramaut, ${ }^{12}$ Yemen. Ia berasal dari keluarga dengan tradisi pendidikan sufistik. Syaikh alHaddâd mendapatkan pengajaran dari kedua orang tuanya. Sayyid Alwi al-Haddâd dan Syarîfah Salmah. Disamping menghafalkan al-Quran, pengetahuan keagamaan telah diberikan sejak usia yang masih belia.

Kehidupan masa remaja Syaikh al-Haddâd, lebih banyak dipenuhi oleh kegiatan beribadah mendekatkan diri kepada Allah, ia cenderung menjauhkan diri dari cara hidup para remaja seusianya. Ia juga tekun menuntut ilmu agama, guruguru beliau adalah para syaikh yang mempunyai kekhususan di bidangnya. Ia juga gemar menziarahi makam-makam para wali untuk mendapatkan barakah dan kekuatan ruhani sebagai bekal dalam menempa diri melawan hawa nafsu. ${ }^{13}$

Dalam pada itu ia tidak pernah beristirahat dalam ber-sulukk demi mendekatkan diri kepada Allah. Sebab begitulah seharusnya yang dilakukan oleh orang yang bersuluk. Seperti yang dituliskannya dalam salah satu suratnya: "Sulûk ialah berjalannya hati menuju kelurusan akhlak keimanan, serta pen-tahqiq-an peringkat-peringkat keyakinan dan segala yang berkaitan dengannya. Perjalanan hati haruslah mendaki dari suatu maqam yang telah dicapai ke arah maqam lainnya yang lebih tinggi secara terus menerus tanpa henti dari sejak awal sampai

\footnotetext{
${ }^{11}$ Lebih lengkap adalah Abdullah b. 'Alawi b. Muhammad b. Ahmad b. Abdullah b. Muhammad alHaddâd b. Alwi b. Ahmad b. Abû Bakar b. Ahmad b. Abû Bakar b. Ahmad b. Muhammad b. Abdullah b. al-Faqih Ahmad b. Abdul Rahman b. Alwi b. Muhammad Shâhib Mirbath b. Ali b. 'Alawi Khala' Qasam b. Ali al-Uraidhi b. Ja'far Shâdiq b. Muhammad al-Bâqir b. Ali Zainal Abidin b. Husein b. Fatimah al-Zahra bt. Muhammad saw. Gelar (kunyah) al-Haddâd dilabelkan kepada leluhurnya yang kelima, Muhammad al-Haddâd. Lihat Muhammad al-Syathiri, al-Mu'jam al-Lathîf Asbâb al-Alqâb wa Kunyi fi al-Nasab al-Syarîf (Jeddah : 'Alam al-Ma'rifah, 1986): 87

${ }^{12}$ Hadhramaut adalah sebagian dari daerah di Arab selatan yang kini masuk ke dalam pemerintahan Yaman (dulu Yaman Selatan). Studi mengenai daerah ini dapat ditemukan pada tulisan Van Den Berg, Le Hadramaut Et Les Colonies Arabes Dans L. Aerchipel Indien, telah diterjemahkan oleh INIS dengan judul Hadhramaut dan Koloni Arab di Nusantara. Buku yang bukan saja membahas Hadhramaut secara geografis, tetapi juga mengikutkan seluruh aspek kehidupan masyarakatnya yang dilakukan oleh Berg pada abad 19.

13 Muhammad bin Zein bin Smith, op cit,.123
} 
akhirnya. Itulah perjalanan batin di atas perjalanan batin pula." 14

Akhirnya, perjuangan yang tak kenal lelah -yang dilakukannya selama puluhan tahun dalam menuntut ilmu dan menyucikan jiwa dari segala perilaku tercela telah mengantarkannya ke puncak kesempurnaan insani. Oleh karena itu, ia berhak memperoleh sebutan sebagai al-Quthb al-Ghawts dalam ilmu hakikat.

Berkenaan dengan kemuliaan yang telah ia capai ini, Sayyid Umar bin Abdul Rahman al-Aththas, yang merupakan salah seorang guru dari al-Haddâd mengatakan bahwa di dalam diri Abdullâh bin Alwi al-Haddâd telah terkumpul antara hakikat, syari'ah dan wilâyah, dan telah mencapai derajat insân al-kâmil. ${ }^{15}$

Kemuliaan dan keutamaan Syaikh al-Haddâd bukan saja terletak pada ilmu batinnya yang telah mencapai derajat tertinggi itu tersebut, dalam ilmu syariat ia telah mencapai derajat mujtahid, yang memiliki kedalaman ilmu keislaman dan tauhid, bahkan hal ini telah ikut mempengaruhi corak pemikiran tasawufnya.

Mengenai hal ini, sayyid Ahmad al-Hinduân ${ }^{16}$ sewaktu ditanya apakah Syaikh al-Haddâd seorang mujtahid atau muqallid. Ia menjawab : "Ia adalah seorang mujtahid, bukan seorang muqallid". Bagaimana tidak, madzhabnya seorang mujtahid adalah al-Kitab dan as-sunnah. ${ }^{17}$ Dengan demikian, maka pemikiran sufistik Syaikh al-Haddâd berbeda dengan paradigma sufistik yang berkembang sebelumnya yang cenderung menjerumuskan orang kepada kejumudan, tapi sebaliknya, pemikiran Syaikh al-Haddâd lebih memberikan arti aktif. $^{18}$

Syaikh al-Haddâd juga dikenal sebagai seorang penulis yang sangat produktif. Karya-karyanya telah menyebar tidak saja di Hadramaut, tetapi juga ke seluruh negeri Islam, terutama di Afrika dan Asia termasuk di Indonesia, Pada setiap majelis pengajian rutinnya yang diselenggarakan, yang biasanya diisi dengan pembacaan buku-buku agama, buku-buku beliau niscaya menjadi inti

14 ibid.

15 ibid,. 104

${ }^{16}$ Seorang tokoh sufi yang hidup semasa dengan Syaikh al-Haddâd, dan sama-sama menimba ilmu pengetahuan dari Syaikh Ahmad al-Qusyasyi. Ia wafat tahun $1120 \mathrm{H}$.

Musthafa Hasan al-Badâwi, Al-Imâm Abdullâh al-Haddâd, Mujaddid al-Qarn al-Tsâni Asyr, (tk, Dâr al-Hâwi, 1994): 84

18 Ahmad abdul Karîm al-Husawi, Tatsbît al-Fuâd, juz 1,(Tarim: al-Hâwi, 1999): 39 
pembahasan, syair-syair gubahannya pun merupakan bahan-bahan utama dalam kasidahan yang biasanya mengakhiri majelis itu. Selain itu, kata-kata mutiaranya selalu menghiasi setiap ceramah atau khutbah yang diucapkan para $d a{ }^{\prime} i$ dan mubalig. Sebutan namanya tidak pernah kering dari lidah-lidah mereka. Hal ini tentu saja menggambarkan betapa luasnya pengaruh karya-karya beliau di dunia Islam. Diwân al-Durr al-Manzhûm li Dzawi al-`Uqûl wa al-Fuhûm adalah Salah satu karya monumentalnya yang sampai sekarang masih terasa pengaruhnya di kalangan muslim di seluruh dunia.

Dîwân ini disusun pada usia 80 tahun. ${ }^{19}$ Usia dimana seseorang telah mencapai puncak kematangan intelektual dan spiritualnya, maka adalah wajar apabila dikatakan bahwa dîwân tersebut (sesuai dengan namanya Li Dzawi al'Uqûl wa al-Fuhûm), di peruntukkan bagi orang-orang yang telah mempunyai tingkat intelektual tertentu. Hal tersebut sebagai mana yang ia katakan sendiri, bahwa di dalam dîwân tersebut mengandung persoalan-persoalan yang tidak terdapat dalam karya-karya beliau sebelumnya. ${ }^{20}$

Syair-syair yang terdapat di dalam dîwân ini, terdiri dua dan tiga baris bait syair. Satu rangkap atau bait syair diikuti oleh bait-bait selanjutnya untuk membawa suatu kesatuan yang lengkap sesuai dengan isinya dan maksud pengarangnya. Keseluruhan jumlah bait syair yang di dalam dîwân tersebut adalah 3675 bait, dengan 39 bait setengah, yang terhimpun dalam 160 syair. Adapun jumlah suku kata di dalam setiap bait syairnya adalah antara 4 sampai 6 atau 7 suku kata. Sedangkan jumlah bait yang terdapat dalam setiap syairnya sangat variatif, ada yang berjumlah dua, empat, sepuluh bahkan ada yang mencapai ratusan bait syair.

Adapun yang melatar belakangi ditulisnya karya dîwân yang terdiri dari 160 syair ini adalah keprihatinannya terhadap kondisi sosio-kultural masyarakat yang mulai cenderung melalaikan kewajiban-kewajiban dan nilai-nilai moral Islam yang suci, tergoda oleh gemerlap dunia, yang akan menjauhkan diri mereka dari Allah. Kondisi ini menurut Syaikh al-Haddâd, corak kehidupan seperti ini sangat

\footnotetext{
${ }^{19}$ Ahmad b. Zein al-Habsyi, Syarah `Ainiyah, (Singapura : Pustaka Nasional, 1987): 379.

${ }^{20}$ Muhammad b. Zein b. Smith, Ghâyât, Op. cit,. 89
} 
bertentangan dengan corak kehidupan para salaf, yang masih sangat teguh memegang prinsip-prinsip ketaqwaan, melaksanakan semua perintah Allah dan menjauhi larangannya, nilai-nilai kesufian begitu kental mencoraki kehidupan mereka sehari-hari. Hal inilah yang mendorong Syaikh al-Haddâd menyusun dîwân ini, dengan harapan mengajak dan mengingatkan mereka untuk kembali ke jalan Allah dan menghidupkan kembali cara hidup sebagaimana yang telah dicontohkan oleh para salaf.

Dîwân al-Haddâd ini, mendapatkan perhatian dan penghargaan yang besar sekali dari para sufi dan ulama yang hidup sesudahnya, baik itu dari kalangan sâdah bâ `alawi maupun dari selain kalangan luar mereka. Mereka pada umumnya menganjurkan untuk membaca dan mempelajari diwân tersebut, karena di dalamnya terkandung rahasia-rahasia (asrâr), pengajaran dan hikmah-hikmah yang berharga, di dalamnya juga terkandung ilmu-ilmu tentang keimanan, syariat dan pandangan-pandangan beliau tentang tasawuf. Dalam kitab Syarah Ratib alHaddâd, karya Sayyid Ahmad bin Hasan al-Haddâd disebutkan: ${ }^{21}$

Wahai penuntut rahasia-rahasia ilmu para guru kami
ahli tasawuf yang menempati maqâm tertinggi
maka lazimkanlah membaca Dîwân al-manzhûm
kau kan dapatkan sari ilmu yang bermanfaat

Secara khusus, berkenaan dengan dîwân ini, Dr. al-Badawi mengatakan:

"Dîwân tersebut adalah bagaikan lautan yang tidak akan pernah kering daripada ilmu, nasehat-nasehat, dakwah, rahasia-rahasia dan hikmah-hikmah yang terdalam. Ia tidak menuliskan suatu syairpun yang terilham di dalam benaknya kecuali setelah berlalu beberapa hari. Seandainya ia masih mengingatnya, maka berarti ia mendapatkan izin dari Allah untuk menyebarkannya, kalau ia lupa maka berarti ia tidak mendapatkan izin dari Allah untuk mengajarkannya. Kasidah-kasidah nya senantiasa dilantunkan diseluruh dunia, baik dibelahan barat maupun timur. Karena di dalamnya penuh dengan ajaran-ajaran yang memberikan motivasi dan semangat di dalam menghadapi kehidupan dunia, dan cinta kepada Allah dan rasul-Nya, di dalamnya juga terdapat wejangan-wejangan dalam menghadapi kehidupan, dan peringatan-peringatan akan kesesatan dan hal-hal yang akan menjauhkan seseorang dari jalan keselamatan. ${ }^{22}$

\section{Karakteristik syair-syair dalam Dîwân durr al-Manzhûm}

Syair-syair di dalam dîwân Durr al-Manzhûm, tidak disusun secara tematis. agaknya al-Haddâd memang tidak berupaya untuk menyusun syair-

${ }^{21}$ Ahmad bin Hasan al-Haddâd, Op. cit,. 125

22 al-Badâwi, Op. cit,. 167 
syairnya secara tematis, tapi membiarkannya mengalir begitu saja, sehingga penulis mengalami kesulitan di dalam menjelajahi pemikiran sufistik beliau, khususnya berkenaan dengan masalah-masalah yang ingin penulis paparkan.

Fakta ini, bagi penulis memperkuat kenyataan bahwa syair-syair Syaikh alHaddâd, bukanlah an sich produk nalar, tapi ia lebih didasarkan pada mauhibah Rabbâniyah, semacam kekuatan inpersonal (ilhâm), sehingga syair-syairnya terlihat sangat spontan dan wajar.

Ciri-ciri lain yang menonjol dalam syair-syair Syaikh al-Haddâd adalah:

1. Dilihat dari struktur lahirnya, syair-syair Syaikh al-Haddâd adalah syair yang berskema akhir AAAA

2. Di lihat dari struktur batinnya, syair-syair Syaikh al-Haddâd merupakan ungkapan pengalaman batin yang diperoleh penyair dari pengalaman melakukan perjalanan spiritualnya (sulûk) atau pengetahuan ruhani penyair tentang ilmu tasawuf yang di dapat melalui ilhâm dan kasyf, serta tersingkapnya mata batin. Syair-syair semacam ini menggunakan tamsil-tamsil khas terutama yang berkenaan dengan anggur, tuak, lautan dan lain-lain.

3. Terdapat beberapa kata dan istilah khas kesufian seperti nafhât al-`anbariyah, bahamût, nasîm, dan lain-lain, yang sulit untuk difahami, kecuali oleh seorang yang telah benar-benar memahami pemikiran sufistik Syaikh al-Haddâd.

4. Syaikh al-Haddâd sering memulai rangkaian syairnya dengan ghazâl (gurauan cinta), tentang cinta dan kerinduan kepada suatu tempat dan pada seseorang teman. tetapi ia menggunakan ghazâl tersebut hanya sebagai media dalam rangka menyampaikan apa yang sesungguhnya yang ingin ia katakan.

5. Terdapat kutipan-kutipan ayat-ayat al-Quran dan hadits Rasulullah di dalam syair-syair beliau, khususnya ayat-ayat yang didalamnya terkandung ajaran esoterik Islam, contohnya: ${ }^{23}$

Berjuanglah maka akan kau saksikan lalu nantikan janji-Nya akan petunjuk-Nya, seperti dalam surah al- 'Ankabût

\section{al-Ghazal dalam syair-syair Syaikh al-Haddâd}

${ }^{23}$ Abdullah b. Alwi al-Haddâd, Diwan al-Durr al-Manzhum Li Dzawi al-`Uqûl wa al-Fuhûm, Mesir : Mathba`ah Isa al-Bâbi al-Halabi wa Syarîkuhu, tt): 57 
Penggunaan ghazâl sangat dominan dalam syair-syair Syaikh al-Haddâd. Sebelum sampai pada sesuatu yang sebenarnya ingin dikatakannya, ia sering memulai syair-nya dengan ghazâl (gurauan syair cinta), yaitu dengan menyebutkan nama-nama tempat yang indah dan penuh kenangan baginya dan orang-orang yang dikaguminya. Ia mengeluhkan pedihnya rasa cinta dan perpisahan, ia juga menyatakan kerinduan yang menggelora pada Sang Kekasih. Kesemuanya itu dirajut dalam bait-bait syairnya yang indah dan mempesona.

Berkenaan dengan kegemaran para sufi menggunakan qhazâl dalam syairsyair mereka, Syaikh al-Haddâd mengatakan: "Makna cinta demikian lembut dan agung, terlalu sulit untuk diuraikan dengan kata-kata, karena walau bagaimanapun kata cinta itu tidak mungkin dapat dipaparkan makna yang sesungguhnya secara gamblang. Tentang bagaimana cinta itu sesungguhnya tidak terjangkau oleh katakata itu, karena itulah kita dapat menyaksikan betapa orang-orang yang tercekam perasaan cinta (ahl al-mahabbah) itu hanya dapat memendam perasaan cinta yang mulia dan sejati itu tanpa mampu mengungkapkanya dengan kata-kata. Mereka memerlukan cara yang dapat menggambarkan perasaan yang berat itu dengan memaparkan itu melalui kata-kata kebalikannya. Makna yang dimaksud dengan kata-kata itu (cinta) sesungguhnya adalah jiwa yang terkandung di dalamnya. Setelah mereka tidak sanggup memaparkan makna melalui ungkapan kata-kata dan citra-citra simbolik. Mereka sering menggunakan kata-kata gurauan (ghazâl) seperti Laila, Su`da, Lubna, Hindun, Da`dun dan lain sebagainya. ${ }^{24}$

Lebih jauh beliau berkata, "Soal-soal yang diutarakan dengan kata-kata gurauan ( $g h a z \hat{a} l$ ), hanya mengenai hal yang berkaitan dengan percakapan antara diri sendiri dan ruh (mukhâtabât al-nafs li al-rûh), tidak mengenai soal-soal yang bersifat ilâhiyah. Karena soal-soal ketuhanan ini amat sulit dan bersifat sangat rahasia (ghâmidh), hampir tak dapat dimengerti kecuali oleh kaum shiddiqîn terkemuka dan berada diluar kesanggupan manusia."

${ }^{24}$ al-Husawi, Op.cit. 
Syaikh al-Haddâd sendiri pernah menggunakan kata-kata seperti itu di dalam syair-syairnya. Sebagai contoh kami kemukakan salah satu syairnya berikut ini: $:^{25}$

Diriku sibuk mencintai Laila
hingga aku lupa akan segalanya
jika kau tanyakan siapakah Dia?
katakanlah: Dia adalah anugerah Tuhan semesta

Syaikh al-Haddâd menjelaskan bahwa "tuak" yang ada pada syair-syairnya itu adalah tuak yang menyenangkan dan suci, bukan tuak duniawi yang menjadi biang semua perbuatan rendah dan nista. Kata-kata gurauan seperti itu disebut juga oleh Syaikh al-Haddâd di dalam syairnya yang lain; ${ }^{26}$

Tuaknya adalah tuak cinta membuanya tergila-gila pada si Dia orang-orang bodoh pasti kan menduga ia mabuk karena anggur yang diharamkan

Dengan demikian, ungkapan-ungkapan simbolik mempunyai peranan yang sangat penting dalam membentuk lapisan-lapisan makna (makna dalam dan luar) bagi suatu puisi, maka kita akan melihat bahwa pemberian makna kepada satu bentuk (shûrah lahir) yang begitu intensif menyebabkan ungkapan puitik menjadi transparan, tetapi dengan demikian makna batin dengan segala kerahasiaannya dapat lebih terungkapkan. Lebih-lebih dalam puisi yang ditulis berdasarkan kasyf dan ilham seperti syair-syair Syaikh al-Haddâd. Di situ makna batin sepenuhnya menguasai bentuk lahir (shûrah) dan pada masa yang sama makna batin sanggup mengemas bentuk lahir dari dalam bukan dari luar.

\section{al-Ritsấ 'dalam Syair Syaikh al-Haddâd}

Syair-syair Ritsâ ${ }^{\prime 27}$ yang terdapat di dalam dîwân Syaikh al-Haddâd, pada umumnya bertemakan ungkapan keperihatinan dan gejolak hatinya yang paling dalam akan kondisi masyarakat di mana ia hidup. Sumber dari kegusaran hatinya

25 al-Haddâd, Dîwân, Op.cit,. 94

${ }^{26} \mathrm{ibid}$, h. 51

${ }^{27}$ Ritsâ' berasal dari kata (رثي الميت يرثيه ويرثوه رثاء), artinya ratapan dan tangisan karena kehilangan sesuatu yang dicintai. Ia juga berarti (رقد (رن ورحم), yaitu mengasihani dan merasa iba pada seseorang. Lihat Husin b. Muhammad al-Haddâr, Rihlah Fi Diwân al-Imâm al-Haddâd, (tk : Ribath alHaddâr Li al-'Ulûm al-Syar`iyyah, tt): 173 
itu adalah keinginannya yang kuat untuk mengembalikan tata cara kehidupan sufistik --sebagaimana yang telah diterapkan oleh salaf- yang kian lama kian memudar, dan kemauannya yang keras untuk menghapuskan dekadensi moral yang telah melanda masyarakatnya. Ketulusan hati, ketajaman intuitif serta amukan jiwanya yang terdalam, terpancar di dalam bait-bait syairnya yang indah mengharukan, sehingga mampu menggetarkan relung-relung hati pembaca.

Sebagai seorang mursyid yang memahami kondisi masyarakatnya, Syaikh al-Haddâd merasa mempunyai tanggung jawab moral yang berat, ia tidak merasa tenang dengan apa yang tengah berlaku di masyarakat. Sayangnya, Syaikh alHaddâd mengeluhkan, sedikit sekali orang yang bersedia membantunya untuk mewujudkan keinginannya tersebut. ${ }^{28}$

Di samping itu, terdapat pula ungkapan-ungkapan kerinduannya pada wâdi ibn Rasyid, ${ }^{29}$ pada penduduknya al-salaf al-shâlih dan pada kehidupan yang penuh dengan kesucian dan kemuliaan serta pada kegiatan ilmiah yang begitu semarak. Akan tetapi semuanya tinggal kenangan saja, telah terjadi begitu banyak perobahan di wâdi tersebut, karena banyaknya ulama yang meninggal dunia menjadikan kehidupan keilmuan tidak semarak lagi. ${ }^{30}$

Wadi ibn Rasyid adalah pujaan hati
agan-angan jiwa dan hayalku
negeri yang sejuk diteduhi awan
disirami hujan yang melimpah ruah
negeri hijau terhampar rumput yang indah
penyegar mata penyejuk jiwa
negeri yang semarak oleh ilmu dan adab
keadilan kebaikan dan syukur
yang sunyi dari segala kekotoran dan kekeruhan
segala kejahatan dan orang-orang jahat
hingga tiba masa kemunduran
karena prilaku jelek penduduknya
yang terkena fitnah dunia dan setan
jauh dari kebenaran dan kesabaran

Di samping tema tersebut di atas, Dalam syair-syair ritsâ' Syaikh alHaddâd, terdapat juga ungkapan kesedihan beliau karena ditinggalkan oleh orang-

\footnotetext{
${ }^{28}$ al-Haddâd, Diwân, Op. cit, h. 120

${ }^{29}$ Wâdi Ibn Rasyid adalah gelar bagi wâdi Hadhramaut, ia dinisbatkan kepada Sultan 'Abdullah ibn Rasyîd al-Qahthâni al-Hâmiri, lahir tahun 553 H. Lihat al-Haddâr, Op. cit,. 181

30 al-Haddâd, Dîwân, Op. cit,. 65
} 
orang yang ia cintai dan sayangi. Syair di bawah ini, menggambarkan kepedihan hatinya manakala ia mengetahui bahwa saudaranya telah meninggal dunia. ${ }^{31}$

\section{KESIMPULAN}

Tulisan ini berupaya mengungkap beberapa aspek penting syair Syaikh al-Haddâd dan menyajikan gambaran berkenaan dengan kepenyairannya. Syair-syair karya Syaikh al-Haddâd merupakan syair-syair sufi teoritis yang kaya akan gagasan dan pengalaman keruhanian. Syair syair tersebut dapat digolongkan ke dalam jenis syi'r al-kasyf wa al-ilhâm, yaitu karya yang ditulis melalui pengalaman kasyf atau penglihatan keruhanian disebabkan penulisnya mencapai makrifat dan persatuan mistik.

Di lihat dari struktur batinnya, syair-syair Syaikh al-Haddâd merupakan ungkapan pengalaman batin yang diperoleh penyair dari pengalaman melakukan perjalanan spiritualnya (sulûk), atau pengetahuan ruhani penyair tentang ilmu tasawuf, yang di dapat melalui ilham dan kasyf, serta tersingkapnya mata batin. Syair-syair semacam ini menggunakan tamsil-tamsil khas terutama yang berkenaan dengan anggur, tuak kekasih, perjalanan, lautan dan lain-lain.

Dari struktur lahirnya, nampak sekali keluasan dan kedalaman pengetahuan bahasanya. Kata-kata yang ia digunakan dalam syair-syairnya adalah kata-kata yang indah dan mudah dicerna, bahasa yang digunakan adalah bahasa yang lugas dan sederhana sehingga mudah untuk difahami. Penggunaan ungkapan-ungkapan simbolik (tamtsil), seperti kekasih, laila, su'dâ, anggur, arak, kemabukan, kefakiran dan ketelanjangan mistik (uryân) adalah perumpamaan yang didasarkan bentuk cinta manusiawi, tetapi bermaksud membawa pembaca kepada yang hakiki.

Ungkapan-ungkapan simbolik itu mempunyai peranan yang sangat penting dalam membentuk lapisan-lapisan makna (makna dalam dan luar) bagi suatu puisi, maka kita akan melihat bahwa pemberian makna kepada satu bentuk (shûrah lahir) yang begitu intensif menyebabkan ungkapan puitik menjadi transparan, tetapi dengan demikian makna batin dengan segala kerahasiaannya dapat lebih terungkapkan. Lebih-lebih dalam puisi yang ditulis berdasarkan kasyf dan ilham

${ }^{31}$ ibid, 116 
seperti syair-syair Syaikh al-Haddâd. Di situ makna batin sepenuhnya menguasai bentuk lahir (shûrah) dan pada masa yang sama makna batin sanggup mengemas bentuk lahir dari dalam bukan dari luar.

Syaikh al-Haddâd sering memulai rangkaian syairnya dengan ghazâl (gurauan cinta), tentang cinta dan kerinduan kepada suatu tempat dan pada seseorang teman. Ia juga menggunakan syair-syair ritsâ', yang merupakan ungkapan kesedihan karena ditinggalkan oleh orang-orang yang dicintai.

Di samping itu, Husn al-takhallus, dan ditambah lagi dengan metode dan $u s h l \hat{b}$ yang ia gunakan dalam bersyair semakin menunjukan bahwa ia bukan saja seorang sufi, tetapi seorang intelektual jenius yang telah mendapatkan wahbah ilâhiyah berupa ilmu laduni.

Fakta ini, bagi penulis memperkuat kenyataan bahwa syair-syair Syaikh alHaddâd, bukanlah an sich produk nalar, tapi ia lebih didasarkan pada mauhibah Rabbâniyah, semacam kekuatan inpersonal (ilham), sehingga syair-syairnya kelihatan sangat bersifat spontan dan wajar.

\section{DAFTAR PUSTAKA}

Arberry, A.J. Pasang Surut Aliran Tasawuf, Diterjemahkan oleh Bambang Herawan. Bandung: Mizan, 1993.

al-Badâwi, Musthafa Hasan. Al-Imâm Abdullâh al-Haddâd, Mujaddid al-Qarn al-Tsâni Asyr. tk: Dar al-Hâwi, 1994.

al-Habsyi, Ahmad bin Zein. Syarh al-`Ainiyyah. Singapura: Pustaka Nasional, 1987 M.

al-Haddâd,, Abdullah b. Alwi. Diwan al-Durr al-Manzhum Li Dzawi al-'Uqûl wa alFuhûm. Mesir : Mathba`ah Isa al-Bâbi al-Halabi wa Syarîkuhu, tt.

al-Haddâr, Husin b. Muhammad. Rihlah Fi Diwân al-Imâm al-Haddâd. tk : Ribath alHaddâr Li al-'Ulûm al-Syar'iyyah, tt.

al-Husawi, Ahmad abdul Karîm. Tatsbît al-Fuâd. juz 1. Tarim: al-Hâwi, 1999.

al-Naisâbûri, Muslim bin al-Hajjâj. Shahih Muslim. Beirut: Dâr Ihyâ al-Turâts al-`Arabi, tt.

al-Syathiri, Muhammad. al-Mu`jam al-Lathîf Asbâb al-Alqâb wa Kunyi fi al-Nasab alSyarîf. Jeddah : 'Alam al-Ma`rifah, 1989.

al-Syâtiri, Muhammad Ahmad. Siyâr as-Salaf min Ban̂̀ `Alawi al-Husainiyyîn. Jeddah: 'Alam al-Ma`rifah, 1985.

al-Syilli, Muhammad bin Abû Bakar. al-Masyra`al-Râwi fi Manâqib al-Kirâm Sâdah Bâ ‘alawi. Juz 2. Beirut: Dâr al-`Ilm li al-Malâyîn, tt.

Hurgronje, Snouck. Nasehat-nasehat Snouck Hurgronje Semasa Kepegawaiannya di Hindia Belanda. Vol.8. Jakarta: INIS.

Smith, Muhammad bin Zein bin. Ghâyah al-Qashd wa al-Murâd. Beirut: Dâr Ihyâ alKutûb al-`Arabi, tt. 
Tamaddun: Jurnal Kebudayaan dan Sastra Islam, Vol. 19 No. 1, Juni 2019 (16-31)

Nasr, Seyyed Hossein. Islamic Art and Spirituality. New York: State University of New York Press, 1963.

W.M, Abdul Hadi. Sastra Sufi, sebuah Antologi. Jakarta: Pustaka Firdaus, 1996. 